\title{
Analisis Pengaruh Current Ratio, DER, TATO dan EBITDA Terhadap Kondisi Financial Distress Pada Perusahaan Manufaktur yang Terdaftar di Bursa Efek Indonesia
}

\author{
Amanda Oktariyani ${ }^{1}$ \\ ${ }^{1}$ Jurusan Akuntansi, Universitas Tridinanti Palembang \\ Email : amanda_oktariyani@yahoo.com
}

\begin{abstract}
ABSTRAK
Penelitian ini bertujuan untuk mengetahui apakah rasio keuangan yang diproksikan dengan Current Ratio (CR), Debt to Equity Ratio (DER) , Total Asset Turnover (TATO), dan Earning Before Interest, Tax, Depreciation and Amortization (EBITDA) berpengaruh terhadap Financial Distress pada perusahaan manufaktur yang terdaftar di BEI periode 2013-2017. Sampel dalam penelitian ini terdiri dari 46 perusahaan manufaktur. Metode analisis data yang digunakan adalah regresi logistik. Hasil penelitian menunjukkan bahwa Total Asset Turnover dan Earning Before Interest, Tax, Depreciation, and Amortization berpengaruh secara parsial terhadap financial distress. Sedangkan Current Ratio dan Debt to Equity Ratio tidak berpengaruh secara parsial terhadap financial distress. Hasil penelitian menunjukkan bahwa Current Ratio (CR) , Debt to Equity Ratio (DER), Total Asset Turnover (TATO) , dan Earning Before Interest,Tax,Depreciation and Amortization (EBITDA) berpengaruh secara simultan terhadap financial distress.
\end{abstract}

Kata Kunci: Current Ratio, Debt to Equity Ratio, Total Asset Turnover, Earning before interest, tax, depreciation, and amortization, financial distress.

\section{ABSTRACT}

This study aims to determine whether the financial ratios that proxied by Current Ratio, Debt to Equity Ratio, Total Asset Turnover, and Earning Before Interest, tax, Depreciation, and Amortization affect to Financial distress in manufacturing companies listed on the IDX from 2013 to 2017. The samples consist of 46 manufacturing companies. The data analysis method used is logistic regression analysis. The results showed that Total Asset Turnover and Earning Before Interest, Tax, Depreciation and Amortization influence partially to Financial Distress. Whereas, Current Ratio and Debt to Equity Ratio has not influence partially to Financial distress. The results showed that Current Ratio (CR), Debt to Equity Ratio (DER), Total Asset Turnover (TATO) and Earning Before Interest, Tax, Depreciation and Amortization (EBITDA) influence simultaneously to Financial Distress on manufacturing companies listed on Indonesia Stock Exchange (IDX) 2013-2017.

Keywords : Current Ratio, Debt to Equity Ratio, Total Asset Turnover, Earning before interest, tax, depreciation, and amortization, financial distress. 


\section{Pendahuluan}

Krisis ekonomi yang terjadi di berbagai Negara atau yang dikenal dengan Krisis keuangan global pada tahun 2008 juga berdampak terhadap perekonomian Indonesia. Dampak krisis ekonomi global terhadap perekonomian Indonesia bisa dilihat dari merosotnya Indeks Harga Saham Gabungan (IHSG) pada Bulan Desember 2008, jatuhnya nilai kapitalisasi pasar serta penurunan volume perdagangan yang sangat tajam hingga nilai tukar Rupiah yang juga terkoreksi tajam (Direktorat Riset Ekonomi dan Kebijakan Moneter, 2009). Di samping itu, krisis ekonomi global ini juga turut membuat turunnya kinerja ekspor sehingga berdampak pada kesulitan keuangan bahkan pemutusan hubungan kerja di berbagai sektor, termasuk sektor manufaktur. Padahal sektor manufaktur merupakan sektor yang memberikan kontribusi yang besar bagi perekonomian Indonesia (Kurniati \& Yanfitri, 2010).

Di tengah kondisi perekonomian yang fluktuatif, banyak perusahaan yang salah menangkap peluang atau salah mengambil langkah strategis sehingga mereka mengalami kebangkrutan. Beberapa perusahaan besar yang mengalami kebangkrutan seperti yang dilansir dalam (www.ekbis. sindonews.com) antara lain Pabrik milik General Motor Indonesia (GMI) yang memproduksi mobil Chevrolet Spin secara resmi ditutup pada Juni 2015 dan Ford Motor Indonesia menutup bisnisnya di Indonesia pada tahun 2016.

Kesulitan keuangan yang terjadi pada perusahaan disebut dengan istilah financial distress. Financial distress menurut Platt dan Platt (2002) dalam Ardiyanto \& Prasetio (2011) adalah tahap penurunan kondisi keuangan perusahaan yang terjadi sebelum terjadi kebangkrutan. Financial Distress yang dialami oleh perusahaan tersebut dapat dikatakan terjadi karena kinerja keuangan yang tidak baik atau kinerja keuangannya terbilang rendah. Kinerja keuangan suatu perusahaan dapat dilihat dari Analisis Laporan Keuangan. Salah satu metode yang sering digunakan adalah Analisis Rasio Keuangan (Moyer, McGuain\& Rao, 2015).

Penelitian mengenai prediksi financial distress ini diawali oleh Altman (1968) dengan menggunakan indikator rasio yang dikenal dengan Z-Score. Kemudian semakin berkembang penelitian tentang financial distress ini dan mulai dikaitkan dengan pemicunya kinerja keuangan, seperti penelitian Almansour (2015) yang memperoleh hasil bahwa rasio likuiditas berpengaruh negatif yang signifikan terhadap financial distress. Kemudian penelitian Andreev (2006) menunjukkan variabel profitabilitas berpengaruh signifikan dalam prediksi financial distress, karena semakin besar nilai profitabilitas maka akan semakin besar kemungkinan perusahaan tidak mengalami financial distress. Hasil penelitian Haq dkk (2013) menunjukkan bahwa rasio profitabilitas dapat digunakan untuk memprediksi kondisi financial distress dimana menurut Atika dkk (2013) menyatakan hubungannya adalah negatif. Sejalan dengan hal tersebut, penelitian ini akan melihat secara lebih luas mengenai pengaruh kinerja keuangan yang diproksikan dengan rasio keuangan terhadap kondisi financial distress pada perusahaan manufaktur. 


\section{Tinjauan Pustaka}

Financial Distress

Financial Distress adalah situasi kondisi perusahaan sedang mengalami kesulitan keuangan dimana arus kas operasi perusahaan tidak cukup untuk memenuhi kewajiban saat ini, seperti kredit perdagangan atau beban bunga (Ross, et.al., 2013). Dengan kata lain, financial distress merupakan suatu kondisi dimana perusahaan mengalami kesulitan keuangan untuk memenuhi kewajibannya. Menurut Pena, et al dalam Hubbansyah dan Wijaya (2013) yang berpendapat bahwa prediksi kebangkrutan sangat penting untuk berbagai organisasi publik dan komersial karena kegagalan perusahaan menyebabkan penyebaran krisis ke bagian lain dari sistem keuangan dan menyebabkan krisis sistemik.

\section{Teori Sinyal (Signalling Theory)}

Sulistyanto (2008) mengatakan bahwa teori sinyal menjelaskan pada dasarnya laporan keuangan dimanfaatkan perusahaan untuk memberikan sinyal positif maupun negatif kepada pemakainya. Menurut Teori sinyal menjelaskan bahwa perusahaan dengan kualitas yang tinggi ingin mensinyalkan nilainya terhadap pihak eksternal. Kualitas yang dimiliki perusahaan disini dapat berarti banyak, misalnya untuk keperluan investasi dan pengembangan perusahaan. Teori sinyal mengemukakan tentang bagaimana seharusnya suatu perusahaan memberikan sinyal kepada pengguna laporan keuangan perusahaan. Sinyal yang diberikan dapat berupa informasi mengenai apa yang telah dilakukan oleh pihak manajemen untuk merealisasikan keinginan dari pemilik perusahaan. Selain itu, sinyal juga dapat berupa informasi lain yang menyatakan bahwa perusahaan tersebut lebih baik dari perusahaan yang lain. Secara lebih formal, pengaruh pemberian sinyal berasumsi bahwa terdapat asimetri (ketidakseimbangan) informasi antara pihak manajemen dan pihak eksternal perusahaan (Horne dan Wachowicz, 2005). Salah satu cara untuk mengurangi asimetri informasi adalah dengan memberikan sinyal pada pihak luar, berupa informasi keuangan yang positif dan dapat dipercaya mengenai prospek perusahaan kedepannya sehingga dapat meningkatkan kesuksesan perusahaan.

\section{Teori Pecking Order}

Teori ini menunjukkan perkembangan Leverage perusahaan serta keputusan manajemen perusahaan mengenai pendanaan. Teori ini pertama kali dipopulerkan oleh Myers pada tahun 1984. Dalam pecking order theory dibagi menjadi 2 pendanaan yaitu pendanaan dari dalam dan pendanaan dari luar. Perusahaan lebih menyukai sumber dana dari dalam atau pendanaan internal seperti laba ditahan atau modal yang dihasilkan dari kegiatan operasional perusahan daripada pendanaan dari luar seperti obligasi dan saham. Menurut Weston dan Copeland dalam Eliu (2014) teori ini juga dikatakan turunnya nilai suatu perusahaan itu diakibatkan oleh tingginya rasio hutang karena semakin tinggi rasio hutang mengakibatkan semakin besar resikonya dan bisa berujung pada potensi kebangkrutan yang dihadapi suatu perusahaan. 


\section{Teori Du Pont}

Analisis Du Pont digunakan untuk mengetahui sejauh mana kemampuan perusahaan dalam mengontrol pengeluaran agar kemungkinan terjadinya penggunaan hutang rendah dan kemampuan perusahaan dalam menggunakan pendapatan dan modal perusahaan dalam menjalankan kegiatan operasional perusahaan. Perubahan laba dapat dipengaruhi oleh perubahan penjualan, biaya dan total aset (Wibowo dan Musdholifah, 2017).

\section{Rasio Keuangan}

Salah satu cara yang digunakan untuk memprediksi financial distress adalah dengan menganalisis rasio keuangan suatu perusahaan (Altman, 1968). Rasio keuangan adalah alat yang digunakan untuk menganalisis kondisi keuangan dan kinerja perusahaan. Perhitungan yang dilakukan di berbagai rasio bertujuan untuk mendapatkan perbandingan yang mungkin akan berguna daripada angka mentahnya itu sendiri (Horne \& Wachowicz, 2005). Analisis terhadap laporan keuangan perusahaan menurut Hanafi (2009) bertujuan untuk mengetahui tingkat keuntungan, tingkat kesehatan dan tingkat resiko suatu perusahaan dengan menghitung data rasio-rasio keuangan perusahaan.

\section{Hipotesis}

Ha1 : Current Ratio berpengaruh negatif terhadap kondisi Financial Distress pada perusahaan manufaktur yang terdaftar di BEI.

$\mathrm{Ha}_{2}$ : Debt to Equity Ratio berpengaruh positif terhadap kondisi Financial Distress pada perusahaan manufaktur yang terdaftar di BEI.

$\mathrm{Ha}_{3}$ : Total Asset Turnover berpengaruh negatif terhadap kondisi Financial Distress pada perusahaan manufaktur yang terdaftar di BEI.

$\mathrm{Ha}_{4} \quad$ : Earning Before Interest, Tax, Depreciation and Amortization berpengaruh negatif terhadap kondisi Financial Distress pada perusahaan manufaktur yang terdaftar di BEI.

Ho : Current Ratio, Debt to Equity Ratio, Total Asset Turnover, Earning Before Interest, Tax, Depreciation and Amortization tidak berpengaruh terhadap kondisi Financial Distress pada perusahaan Manufaktur yang terdaftar di BEI.

\section{Metode Penelitian}

\section{Populasi dan Sampel}

Populasi dalam penelitian ini adalah seluruh perusahaan Manufaktur yang terdaftar di Bursa Efek Indonesia (BEI) berjumlah 144 perusahaann. Metode yang digunakan dalam menentukan sampel dalam penelitian ini adalah metode purposive sampling yang merupakan teknik pengambilan sampel dengan menentukan kriteriakriteria tertentu. Berdasarkan kriteria yang telah ditentukan, terdapat 46 sampel perusahaan yang masuk dalam kriteria.

\section{Variabel Penelitian \\ Variabel Dependen}

Variabel dependen dalam penelitian ini adalah financial distress dengan menggunakan variabel dummy. Kriteria yang digunakan dalam mengukur variabel dummy adalah perusahaan dinyatakan financial distress (FD) jika EPS negatif berturut-turut selama 2 tahun dan diberi kode angka "1". Sedangkan perusahaan 
tidak mengalami financial distress (NFD) apabila EPS positif berturut-turut selama 2 tahun dan diberi kode angka "0" sesuai dengan penelitian Prasetiono (2011). Sementara variabel independen yang digunakan adalah Current ratio, Debt to Equity Ratio, Total Asset Turnover dan EBITDA.

\section{Variabel Independen}

\section{Current Ratio}

Current ratio atau rasio lancar adalah rasio yang menunjukkan sejauh dimana aktivitas lancar dapat difungsikan untuk menutupi kewajiban jangka pendek atau hutang menjadi lancar. Semakin besar kewajiban yang harus dibayar maka semakin tinggi kemampuan suatu perusahaan untuk dapat menutupi kewajiban jangka pendek. Current Ratio diperoleh dengan membagi aset lancar dan kewajiban lancar.

\section{Debt to Equity Ratio (DER)}

Debt to Equity Ratio merupakan rasio yang menunjukkan kemampuan perusahaan dalam membayar utang dengan modal sendiri. Rumus dari Debt to Equity Ratio yaitu total hutang dibagi dengan total ekuitas.

\section{Total Asset Turnover (TATO)}

Total Asset Turnover merupakan perbandingan antara penjualan dengan total aktiva suatu perusahaan dimana rasio ini menggambarkan kecepatan perputarannya total aktiva dalam satu periode tertentu. Rumus dari Total Asset Turnover yaitu total penjualan dibagi dengan total aset yang dimiliki perusahaan.

\section{Earning Before Tax, Depreciation and Amortization (EBITDA)}

Earning Before Interest, Tax, Depreciation and Amortization (EBITDA) merupakan rasio yang digunakan untuk menganalisis profitabilitas operasi sebuah perusahaan sebelum beban non operasi (seperti bunga dan beban lainnya) dan depresiasi serta amortisasi. Rumus dari EBITDA yaitu :

$$
\text { EBITDA }=\text { EBIT + DEPRECIATION + AMORTIZATION }
$$

\section{Hasil Penelitian Uji Multikolinieritas}

Tabel 1. Uji Multikolinearitas

\begin{tabular}{cccl}
\hline & Tolerance & VIF & Hasil \\
\hline CR &, 825 & 1,212 & Tidak terjadi multikolinearitas \\
DER &, 832 & 1,201 & Tidak terjadi multikolinearitas \\
TATO &, 975 & 1,025 & Tidak terjadi multikolinearitas \\
EBITDA &, 999 & 1,001 & Tidak terjadi multikolinearitas
\end{tabular}

Sumber: Data Sekunder yang diolah, 2018

Berdasarkan hasil uji multikolinearitas pada tabel 4.2 nilai variance menunjukkan bahwa tidak ada variabel independen yang mempunyai nilai tolerance $<0,10$ dan tidak ada nilai VIF $>10$. Dapat disimpulkan bahwa semua variabel CR, DER, TATO dan EBITDA memenuhi kriteria bebas dari multikolinearitas. Dengan kata lain, model regresi layak untuk digunakan. 
Analisis Regresi Logistik

Tabel 2. Pengkodean Variabel Dependen

Dependent Variable Encoding

\begin{tabular}{lcc}
\hline Original Value & Internal Value & Jumlah \\
\hline NON FINANCIAL DISTRESS & 0 & 120 \\
FINANCIAL DISTRESS & 1 & 48 \\
\hline
\end{tabular}

Sumber: Data Sekunder yang diolah, 2018

Dalam penelitian ini, untuk mengetahui jumlah perusahaan untuk kategori "0" dan "1" dapat dilihat dari apabila masuk kategori "0" perusahaan mengalami EPS positif berturut-turut selama 2 tahun, dan apabila masuk kategori "1" perusahaan mengalami EPS negatif selama 2 tahun berturut-turut. Terdapat jumlah 120 perusahaan dikategorikan dalam perusahaan Non Financial Distress dan 48 perusahaan dikategorikan dalam perusahaan Financial Distress.

Uji Kelayakan Model Regresi (Uji Hosmer and Lemeshow's Goodness of Fit)

Tabel 3. Uji Kelayakan Model Regresi

Hosmer and Lemeshow Test

\begin{tabular}{cccc}
\hline Step & Chi-square & Df & Sig. \\
\hline 1 & 9,059 & 8 &, 337 \\
\hline
\end{tabular}

Sumber: Data Sekunder yang diolah, 2018

Dari tabel di atas menunjukkan bahwa nilai statistik (Chi-square) yang dihasilkan dalam Hosmer and Lemeshow's Goodness of Fit sebesar 9,059 dan dengan nilai probabilitas signifikansi sebesar 0,337 atau lebih dari 0,05 maka model dikatakan fit atau tidak ada perbedaan yang nyata antara klasifikasi yang diprediksi dengan klasifikasi yang diamati dan dapat diterima.

\section{Uji Kesesuaian Model (Overall Model Fit)}

Hasil uji overall model fit menunjukkan nilai -2Log Likehood (Block Number=1) terdapat angka-angka sebesar 188.916, 187.601, 186.672 dan 181.090 serta 181.089 dimana angka yang dihasilkan dari model yang memasukkan konstanta dan variabel independen menurun. Pada Block Number=1 ini, angka yang digunakan adalah angka 139,944. Hal ini dapat disimpulkan bahwa angka di -2Log Likehood pada masing-masing tabel, dimana pada awal (Block Number=0) angka yang dihasilkan -2Log Likehood sebesar 201,140 sedangkan pada Block Number=1 angka yang dihasilkan -2Log Likehood turun menjadi 181,089. Hal ini menunjukkan bahwa model regresi yang dihipoteskan fit dengan data. 
Koefisien NagelKerke R Square

Tabel 4. Hasil Cox \& Snell R Square dan Nagelkerke R Square

\begin{tabular}{cccc}
\hline Step & -2 Log likelihood & Cox \& Snell R Square & Nagelkerke R Square \\
\hline 1 & 181,089 &, 112 &, 160 \\
\hline
\end{tabular}

Sumber: Data Sekunder yang diolah, 2018

Pada Tabel 4.6 di atas menunjukkan bahwa nilai Nagelkerke R Square sebesar 0,160 yang berarti bahwa variabiliatas variabel dependen yang dapat dijelaskan oleh variabel independen adalah sebesar $16 \%$ sedangkan $84 \%$ dijelaskan oleh variabelvariabel diluar model penelitian.

\section{Uji Simultan (Omnibus Test)}

Omnibus Test merupakan analisis yang digunakan untuk menguji pengaruh secara simultan antara variabel independen terhadap variabel dependen. Berdasarkan Tabel 4.7 Omnibus Test menunjukkan bahwa hasil nilai signifikansi yang diperoleh sebesar 0,001 atau kurang dari 0,05. Hal ini menunjukkan bahwa variabel independen dalam penelitian ini berpengaruh terhadap variabel dependen secara bersama-sama.

Tabel 5. Hasil Omnibus Test

\begin{tabular}{ccccc}
\hline & Chi-square & Df & Sig. \\
\hline Step 1 & Step & 19,930 & 4 &, 001 \\
& Block & 19,930 & 4 &, 001 \\
& Model & 19,930 & 4 &, 001 \\
\hline
\end{tabular}

Sumber: Data Sekunder yang diolah, 2018

Uji Parsial ( Pengujian Koefisien Regresi)

Tabel 6. Hasil Uji Koefisien Regresi

\begin{tabular}{llcccc}
\hline & B & Wald & df & Sig. \\
\hline Step 1a & CR &,- 000 &, 068 & 1 &, 0794 \\
& DER &,- 510 & 1,729 & 1 &, 189 \\
& TATO & $-1,257$ & 5,735 & 1 &, 017 \\
& EBITDA & -.041 & 8,645 & 1 &, 003 \\
& Constant & 1,566 & 2,988 & 1 &, 084
\end{tabular}

Sumber: Data Sekunder yang diolah, 2018

Berdasarkan pada tabel di atas, diperoleh persamaan regresi logistik sebagai berikut: 


$$
\begin{gathered}
\log _{i t} \mathrm{P}=1,566+(-0,000)(\mathrm{CR})+(-0,510)(\mathrm{DER})+(-1,257)(\mathrm{TATO})+(-0,041)(\text { EBITDA }) \\
+\mathrm{e}
\end{gathered}
$$

Berdasarkan Tabel hasil uji koefisien regresi yang telah dilakukan dapat diambil kesimpulan sebagai berikut:

Pada variabel current ratio dihasilkan koefisien regresi sebesar -0,000 dengan profitabilitas tingkat signifikan sebesar 0,794 lebih besar dari tigkat signifikan yang diharapkan $(0,794>0,05)$ maka tidak terdapat pengaruh yang signifikan pada variabel current ratio terhadap financial distress. Dengan demikian berarti hipotesis pertama $\left(\mathrm{H}_{\mathrm{a} 1}\right)$ ditolak.

Pada variabel debt to equity ratio dihasilkan koefisien regresi sebesar -0,510 dengan profitabilitas tingkat signifikan sebesar 0,189 lebih besar dari tigkat signifikan yang diharapkan $(0,189>0,05)$ maka tidak terdapat pengaruh yang signifikan pada variabel debt to equity ratio terhadap financial distress. Dengan demikian berarti hipotesis kedua $\left(\mathrm{H}_{\mathrm{a} 2}\right)$ ditolak.

Pada variabel total asset turnover dihasilkan koefisien regresi sebesar -1,257 dengan profitabilitas tingkat signifikan sebesar 0,017 lebih kecil dari tigkat signifikan yang diharapkan $(0,017<0,05)$ maka terdapat pengaruh yang signifikan pada variabel total asset turnover terhadap financial distress. Dengan demikian berarti hipotesis ketiga $\left(\mathrm{H}_{\mathrm{a} 3}\right)$ diterima.

Pada variabel EBITDA dihasilkan koefisien regresi sebesar -0,041 dengan profitabilitas tingkat signifikan sebesar 0,003 lebih kecil dari tigkat signifikan yang diharapkan $(0,003<0,05)$ maka terdapat pengaruh yang signifikan pada variabel EBITDA terhadap financial distress. Dengan demikian berarti hipotesis keempat $\left(\mathrm{H}_{\mathrm{a}} 4\right)$ diterima.

\section{Ketetapan Prediksi Model Regresi Logistik}

Untuk melihat suatu ketetapan model prediksi yang digunakan dalam penelitian ini, dapat dilihat pada Tabel 7 yang merupakan tabel predicted values dari suatu keadaan perusahaan dan baris merupakan data aktual yang dapat dilihat pada tabel dibawah ini.

Tabel 7 Ketetapan Prediksi

Classification Table ${ }^{a}$

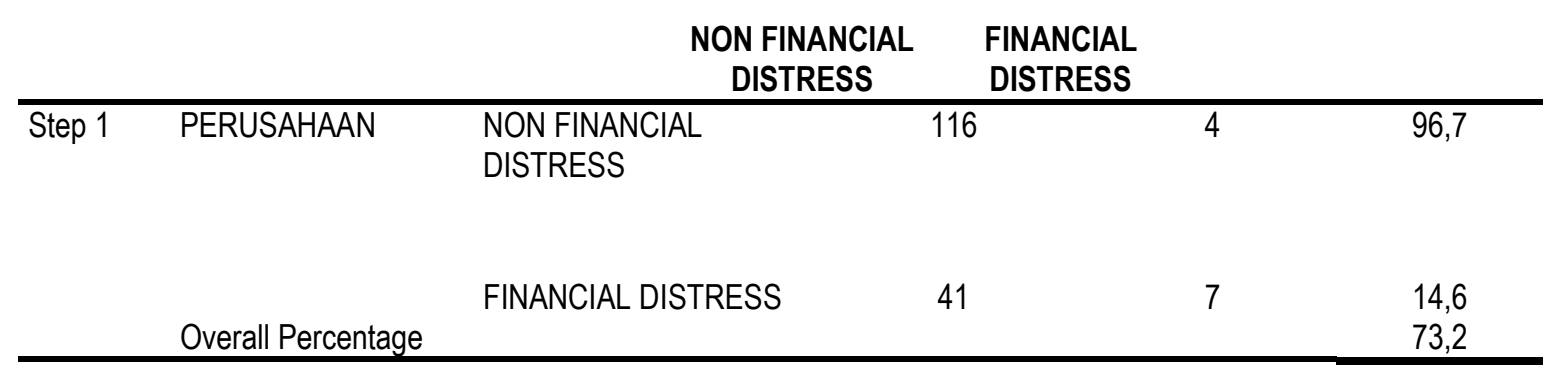

Sumber: Data Sekunder yang diolah, 2018

Tabel 7 di atas merupakan dua nilai prediksi dari variabel dependen dalam hal ini status perusahaan NON FINANCIAL DISTRESS (0) dan FINANCIAL DISTRESS (1) 
sedangkan pada baris menunjukkan nilai observasi yang sesungguhnya dari variabel dependen kategori perusahaan NON FINANCIAL DISTRESS (0) dan FINANCIAL DISTRESS (1). Hasil olah data pada tabel tersebut menunjukkan bahwa prediksi perusahaan yang mengalami non financial distress sebanyak 120 perusahaan sedangkan hasil observasi ada 116 perusahaan dan 4 perusahaan mengalami financial distress. Jadi, ketetapan kalsifikasi model untuk perusahaan yang non financial distress adalah 96,7\%. Selanjutnya, prediksi perusahaan yang mengalami financial distress sebanyak 48 perusahaan sedangkan hasil observasi ada 41 perusahaan yang mengalami financial distress dan ada 7 perusahaan yang non financial distress. Dari penjelasan tersebut, dapat disimpulkan bahwa ketetapan klasifikasi model untuk perusahaan financial distress adalah 14,6\%. Dengan demikian, hasil nilai ketetapan prediksi secara keseluruhan sebesar 85,4\%.

\section{Pembahasan}

\section{Pengaruh Current Ratio terhadap Financial Distress}

Hasil yang diperoleh dari uji hipotesis menunjukkan bahwa Current Ratio (CR) tidak berpengaruh terhadap Financial Distress. Padahal seharusnya CR merupakan variabel yang berpengaruh terhadap Financial Distress. Dengan kata lain, hal ini berarti apabila Current Ratio (CR) perusahaan meningkat maka probabilitas perusahaan mengalami Financial Distress semakin rendah, dan sebaliknya apabila Current Ratio (CR) perusahaan menurun maka probabilitas perusahaan mengalami Financial distress semakin tinggi.

Kasmir (2008) menyatakan bahwa rasio lancar atau current ratio merupakan rasio untuk mengukur kemampuan perusahaan dalam membayar kewajiban jangka pendek atau utang yang segera jatuh tempo pada saat ditagih secara keseluruhan. Dengan kata lain, berapa banyak aktiva lancar yang tersedia untuk menutupi kewajiban jangka pendek yang segera jatuh tempo. Jadi apabila rasio rendah, dikatakan bahwa perusahaan kurang modal untuk membayar utang. Namun apabila hasil pengukuran rasio tinggi, belum tentu kondisi perusahaan baik. Hal ini dapat saja terjadi karena kas tidak digunakan sebaik mungkin. Apabila suatu perusahaan kesulitan untuk membayar utang dengan menggunakan kas yang dimiliki oleh perusahaan, berarti menunjukkan bahwa perusahaan tersebut lebih banyak memiliki hutang dibanding dengan kas atau harta yang dimiliki oleh perusahaan sehingga perusahaan memberikan sinyal keuangan yang tidak baik. Menurut penjelasan Horne dan Wachowicz (2005) pada teori signaling menyatakan bahwa pengaruh pemberian sinyal berasumsi bahwa terdapat asimetri (ketidakseimbangan) informasi antara pihak manajemen dan pihak internal perusahaan. Salah satu cara untuk mengurangi asimetri informasi adalah memberikan sinyal pada pihak luar berupa informasi keuangan yang dapat dipercaya mengenai prospek perusahaan kedepannya sehingga dapat meningkatkan perusahaan. Jadi sinyal yang diberikan oleh perusahaan harus dapat terpercaya. Apabila perusahaan memberikan sinyal yang tidak baik menandakan perusahaan memiliki laporan keuangan yang tidak bagus dan menunjukkan bahwa probabilitas perusahaan tersebut mengalami financial distress semakin besar.

Namun demikan, hasil penelitian ini menunjukkan bahwa Current Ratio tidak berpengaruh terhadap kondisi Financial Distress. Hal ini dimungkinkan terjadikarena pada data sampel yang digunakan dalam penelitian ini beberapa 
perusahaan dengan Current Ratio yang sangat tinggi malah termasuk dalam kategori Financial Distress karena memang dalam dekade terakhir ini sektor manufaktur masih sulit untuk meningkat. Hasil penelitian ini sejalan dengan Mas'ud dan Srengga (2012) serta Putri dan Merkusiwati (2014) yang menyatakan bahwa current ratio tidak berpengaruh signifikan dan tidak dapat digunakan untuk mengukur kondisi financial distress perusahaan. Dengan demikian, Hipotesis 1 (Ha1) yang menyatakan bahwa CR berpengaruh terhadap Financial Distress ditolak.

\section{Pengaruh Debt to Equity Ratio terhadap Financial Distress}

Hasil yang diperoleh dari uji hipotesis perhitungan menunjukkan bahwa Debt To Equity Ratio (DER) berpengaruh negatif tidak signifikan terhadap Financial Distress. Ini berarti bahwa DER tidak berpengaruh terhadap Financial Distress. Kasmir (2008) menyatakan bahwa rasio debt to equity ratio digunakan untuk mengukur sejauh mana perusahaan dibiayai dengan hutang. Rasio DER mencerminkan besarnya proporsi antara total debt (total hutang) dengan total shareholder's equity (total modal sendiri). Rendahnya nilai DER menunjukkan semakin kecil proporsi utang perusahaan terhadap ekuitas perusahaan dan apabila perusahaan lebih memiliki banyak modal sendiri daripada utang berarti perusahaan tersebut mampu dalam mengontrol pengeluaran daripada pemasukan. Hal ini dapat menguntungkan perusahaan sehingga probabilitas perusahaan akan mengalami financial distress semakin kecil. Berdasarkan hasil penelitian yang menyatakan bahwa DER tidak memiliki pengaruh terhadap financial distress, peningkatan maupun penurunan DER tidak berpengaruh terhadap financial distress. Hal ini bertolak belakang dengan teori pecking order yang menyebutkan bahwa turunnya nilai suatu perusahaan itu diakibatkan oleh tingginya rasio hutang karena semakin tinggi rasio hutang mengakibatkan semakin besar resikonya dan bisa berujung pada potensi kebangkrutan yang dihadapi suatu perusahaan.. Berdasarkan teori tersebut maka dapat diketahui bahwa DER yang tinggi dapat menyebabkan probabilitas perusahaan mengalami financial distress semakin besar. Hasil penelitian yang menunjukkan bahwa DER tidak berpengaruh signifikan mengindikasikan bahwa ada beberapa perusahaan sampel dalam perusahaan Manufaktur lebih memiliki banyak modal sendiri daripada utang, berarti perusahaan tersebut mampu dalam mengontrol pengeluaran daripada pemasukan. Hal ini dapat menguntungkan perusahaan sehingga probabilitas perusahaan akan mengalami financial distress kecil. Hasil DER yang tidak berpengaruh dikarenakan nilai DER yang tinggi menunjukkan hutang perusahaan tidak teratur. Dalam tabel rata-rata DER pada perusahaan Manufaktur, nilai DER fluktuatif karena mengalami kenaikan dan penurunan yang tidak konsisten dari tahun 2013-2017. Pada perusahaan sampel Manufaktur yang digunakan memiliki kebijakan struktur modal yang seimbang. Apabila struktur modal perusahaan seimbang maka hutang perusahaan akan semakin mengecil dan profit atau laba perusahaan akan meningkat sehingga semakin kecilnya financial distress perusahaan. Semua perusahaan mempunyai kebijakan hutang sampai titik tertentu untuk mengukur dan mengendalikan tingkat hutang perusahaannya sehingga tidak terjadinya financial distress. Apabila tingkat hutang perusahaan terkontrol dengan baik maka probabilitas perusahaan tersebut mengalami financial distress semakin kecil. Meskipun pada dasarnya rasio DER dapat meningkatkan kondisi financial distress, namun dengan tingkat leverage yang tinggi dapat meningkatkan kegiatan operasional sehingga perusahaan tetap dapat mempertahankan keberlangsungan usahanya. 


\section{Pengaruh Total Asset Turnover terhadap Financial Distress.}

Hasil yang diperoleh dari uji hipotesis menunjukkan bahwa Total Asset Turnover (TATO) berpengaruh negatif signifikan terhadap Financial Distress. Nilai TATO pada perusahaan sampel Manufaktur dalam penelitian ini mengalami penurunan terus menerus dari tahun 2013-2017. Walaupun dalam tabel rata-rata nilai TATO mengalami penurunan, tapi nilai TATO tersebut masih bisa mendanai operasional perusahaan. Berdasarkan hasil penelitian ini yang menyatakan bahwa TATO berpengaruh negatif signifikan terhadap financial distress, peningkatan maupun penurunan TATO dapat mempengaruhi financial distress. Nilai TATO pada perusahaan sampel Manufaktur dalam penelitian ini mengalami penurunan terus menerus dari tahun 2013-2017. Walaupun dalam tabel rata-rata nilai TATO mengalami penurunan, tapi nilai TATO tersebut masih bisa mendanai operasional perusahaan. Nilai TATO yang kecil bisa disebabkan karena ada aset yang belum dipotimalkan secara baik untuk mendapatkan laba, sehingga penjualan lebih tinggi dibanting aset yang dimiliki sehingga perusahaan tidak mengalami laba. Apabila penjualan meningkat menyebabkan biaya menurun dan laba yang didapatkan juga semakin menurun. Semakin tidak efektif perusahaan menggunakan aktivanya untuk menghasilkan penjualan maka dapat memberikan kerugian yang semakin besar bagi perusahaan. Hal ini menunjukkan kinerja yang tidak baik, sehingga dapat mempengaruhi keuangan perusahaan dan memicu terjadinya financial distress. Hasil penelitian ini sejalan dengan hasil penelitian yang dilakukan oleh Noviandri (2014) yang mengindikasikan bahwa nilai TATO yang semakin kecil dapat menyebabkan terjadinya financial distress. Dengan demikian, Hipotesis $3\left(\mathrm{H}_{3}\right)$ yang menyatakan bahwa TATO berpengaruh terhadap Financial Distress diterima.

\section{Pengaruh Earning Before Interest, Tax, Depreciation and Amortization (EBITDA) terhadap Financial Distress.}

Hasil yang diperoleh dari uji hipotesis menunjukkan bahwa Earning Before Interest, Tax, Depreciation and Amortization (EBITDA) berpengaruh negatif signifikan terhadap Financial Distress. Ini berarti apabila EBITDA perusahaan meningkat maka probabilitas perusahaan mengalami Financial Distress semakin rendah, dan sebaliknya apabila EBITDA perusahaan menurun maka probabilitas perusahaan mengalami Financial distress semakin tinggi. EBITDA digunakan untuk melakukan estimasi cash flow yang artinya ketersediaan arus kas yang diproyeksi oleh EBITDA digunakan perusahaan untuk berinvestasi meningkatkan asset tetapnya. Semakin tinggi asset tetap yang dimiliki oleh perusahaan, maka semakin kecil kemungkinan perusahaan tersebut mengalami financial distress. Dengan demikian, perusahaan akan memberikan sinyal kepada pengguna laporan keuangan apakah perusahaan tersebut dalam kondisi yang baik atau tidak. Teori Sinyal yang menyatakan bahwa bagaimana seharusnya suatu perusahaan memberikan sinyal kepada pengguna laporan keuangan perusahaan. Sinyal yang diberikan berupa informasi mengenai apa yang telah dilakukan oleh manajemen untuk merealisasikan keinginan dari perusahaan. Dalam penelitian ini, nilai EBITDA pada perusahaan sampel Manufaktur secara umum relatif kecil, sehingga nilai EBITDA yang kecil memberikan sinyal informasi bahwa perusahaan yang menjadi sampel dalam penelitian ini berpengaruh terhadap kondisi financial distress. Hasil dari nilai EBITDA yang kecil dalam penelitian menunjukkan perusahaan sampel Manufaktur tidak mampu dalam menghasilkan 
laba sebelum bunga dan pajak dari depresiasi dan amortisasi yang digunakan. Ketidakmampuan perusahaan akan menyebabkan kerugian berupa modal yang diperoleh digunakan untuk membayar utang-utang perusahaan. Hasil penelitian yang menunjukkan bahwa EBITDA berpengaruh terhadap financial distress dikarenakan pada perusahaan sampel, nilai EBITDA yang dihasil oleh perusahaan rendah, sehingga adanya kemungkinan perusahaan mengalami financial distress. Hasil penelitian ini sejalan dengan hasil penelitian yang dilakukan oleh Aryanto \& Farahmita (2013) yang menyatakan EBITDA berpengaruh terhadap financial distress dan menolak hasil penelitian yang dilakukan oleh Platt \& Platt (2002) menyatakan bahwa EBITDA tidak berpengaruh terhadap financial distress. Dengan demikian, Hipotesis $4\left(\mathrm{H}_{4}\right)$ yang menyatakan bahwa EBITDA berpengaruh terhadap Financial Distress diterima.

\section{Pengaruh CR, DER, TATO dan EBITDA terhadap Financial Distress}

Hasil Omnibus Test (uji simultan) menunjukkan bahwa Current Ratio (CR), Debt to Equity Ratio (DER), Total Asset Turnover (TATO) dan Earning Before Interest, Tax, Depreciation and Amortization (EBITDA) berpengaruh secara simultan terhadap Financial Distress. Hal ini ditunjukkan dengan hasil Omnibus Test yang menunjukkan bahwa hasil nilai signifikansi yang diperoleh sebesar 0,001 atau kurang dari 0,05. Hal ini menunjukkan bahwa variabel independen dalam penelitian ini berpengaruh terhadap variabel dependen secara bersama-sama dan memiliki hubungan yang cukup kuat, Dengan demikian hipotesis kelima $\left(\mathrm{H}_{0}\right)$ yang menyatakan bahwa current ratio (CR), debt to equity ratio (DER), total asset turnover (TATO) dan earning before interest, tax, depreciation and amortization (EBITDA) tidak berpengaruh terhadap Financial Distress tidak dapat diterima.

\section{Kesimpulan dan Saran \\ Kesimpulan}

Current ratio (CR) secara parsial tidak berpengaruh terhadap financial distress. Hasil penelitian ini terjadi karena pada data sampel yang digunakan dalam penelitian ini beberapa perusahaan dengan Current Ratio yang tinggi termasuk ke dalam kategori Financial Distress, begitu juga sebaliknya sehingga hasil penelitiannya tidak sesuai dengan hipotesis yang diajukan.

Debt to equity ratio (DER) secara parsial tidak berpengaruh terhadap financial distress. Hal ini bertolak belakanh dengan teori yang menyebutkan bahwa debt to equity ratio berpengaruh terhadap financial distress dikarenakan rendahnya nilai DER menunjukkan semakin kecil proporsi utang perusahaan terhadap ekuitas perusahaan dan apabila perusahaan lebih memiliki banyak modal sendiri daripada utang berarti perusahaan tersebut mampu dalam mengontrol pengeluaran daripada pemasukan.

Total Asset Turnover (TATO) secara parsial berpengaruh signifikan terhadap financial distress. Hasil penelitian yang menunjukkan bahwa total asset turnover berpengaruh terhadap financial distress dikarenakan rasio total asset turnover yang rendah menunjukkan perusahaan tidak efektif menggunakan aktivanya untuk menghasilkan penjualan.

Earning Before Interest, Tax, Depreciation and Amortization (EBITDA) secara parsial berpengaruh signifikan terhadap financial distress. Dalam penelitian ini, nilai EBITDA 
secara umum relatif kecil, sehingga nilai EBITDA yang kecil memberikan sinyal informasi bahwa perusahaan yang menjadi sampel dalam penelitian ini berpengaruh terhadap kondisi financial distress.

Current Ratio (CR), Debt to Equity Ratio (DER), Total Asset Turnover (TATO) dan Earning Before Interest, Tax, Depreciation and Amortization (EBITDA) secara simultan berpengaruh terhadap financial distress pada perusahaan manufaktur Indonesia.

\section{Saran}

Berdasarkan hasil analisis dan pembahasan dalam penelitian ini, maka saran-saran yang dapat diberikan bagi investor yaitu disarankan sebaiknya memperhatikan rasio keuangan yang berpengaruh signifikan terhadap financial distress untuk menghindari kebangkrutan. Sedangkan bagi peneliti selanjutnya disarankan untuk meneliti variabel-variabel lain yang belum digunakan dalam penelitian ini dengan objek yang lebih luas dan periode pengamatan yang lebih lama sehingga hasil yang diperoleh dapat lebih jelas dan lebih tepat.

\section{Acknowledgement}

Peneliti mengucapkan terima kasih kepada Yayasan Pendidikan Nasional Tridinanti (YPNT) atas dukungan yang telah diberikan, baik dukungan moril maupun materil dalam pelaksanaan penelitian ini.

\section{Referensi}

Almansoer, Bashar Yaser. 2015. Empirical Model for Predicting Financial Failure. American Journal of Economics, Finance and Management Vol. 1 No.3, pp.113124.

Altman, Edward I. 1968. Financial Ratios, Discriminant Analysis and The Prediction of Corporate Bankruptcy. The Journal of Finance Vol. XXII No. 4.

Andreev, Yuriy Andreev. 2006. Predicting Financial Distress of Spanish Companies.

Ardiyanto, Feri Dwi \& Prasetiono. 2011. Prediksi Rasio Keuangan Terhadap Kondisi Financial Distress Perusahaan manufaktur yang Terdaftar di BEI. Jurnal Dinamika Ekonomi \& Bisnis Vol. 8 No.1.

Aryanto, Reza Putra \& Aria Farahmita. 2013. Hubungan EBITDA Terhadap Intensitas Investasi : Studi Empiris Pada Perusahaan yang Terdaftar di BEI.

Atika, Darminto \& Siti ragil Handayani. 2013. Pengaruh Beberapa Rasio Keuangan Terhadap Prediksi Kondisi Financial Distress. Jurnal Administrasi Bisnis Vol. 1 No. 2.

Direktorat Riset Ekonomi dan Kebijakan Ekonomi. 2009. Outlook Ekonomi Indonesia Tahun 2009 - 2014 : Krisis Keuangan Global dan Dampaknya Terhadap Perekonomian Indonesia. 
Eliu, Viggo. 2014. Pengaruh Financial Leverage dan Firm Growth Terhadap Financial Distress. Jurnal FINESTA Vol. 2 No. 2, pp. $6-11$.

Freedman, Martin and Bikki Jaggi. 2010. Sustainability Enviromental Performance And Disclosures. UK : Emerald Group Publishing Limited.

Hanafi, Mamduh dkk. 2009. Analisis Laporan Keuangan Edisi 4. UPP STIM YKPN : Yogyakarta.

Haq dkk. 2013. Analisis Rasio Keuangan Dalam Memprediksi Financial Distress (Studi Pada Perusahaan yang Terdaftar di BEI). Jurnal Akuntansi Pascasarjana Universitas Syiah kuala ISSN 2302-0164 Vol. 2 No.1, pp. 37- 46.

Horne, James C.Van dan John M.Wachowicz, JR. 2005. Prinsip-Prinsip Manajemen Keuangan. Jakarta: Salemba Empat.

Hubbansyah, Aulia Keiko \& Chandra Wijaya. 2013. Model Kebangkrutan dengan MDA dan BLR Terhadap Perusahaan yang Delisting pada BEI Tahun 2008 2012. Jurnal Fisip Universitas Indonesia.

Kurniati, Yati \& Yanfitri. 2010. Dinamika Industri Manufaktur dan Respon Terhadap Siklus Bisnis. Buletin Ekonomi Moneter dan Perbankan Oktober 2010.

Mas'ud, Imam \& Reva Maymi Srengga. 2012. Analisis Rasio Keuangan Untuk MemprediksiKondisi Financial Distress Perusahaan manufaktur yang Terdaftar di BEI. Jurnal Akuntansi Universitas Jember Vol. 10, No.2.

Moyer, McGuigan, Rao. 2015. Contemporary Financial Management, Thirteenth Edition. USA : Cengange Learning.

Noviandri, Tio. 2014. Peranan Analisis Rasio Keuangan Dalam Memprediksi Kondisi Financial Distress Perusahaan Sektor Perdagangan. Jurnal Ilmu Manajemen Vol.2 No. 4, Oktober 2014.

Platt,H \& Platt, M.B. 2002. Predicting Financial Distress. Journal of Financial Service Professionals, 56 (3) : 12 - 15.

Peter \& Joseph. 2011. Analisis Kebangkrutan dengan Metode Z-Score Altman, Springate dan Zmijewski Pada PT. Indofood Sukses Makmur Tbk. Jurnal Ilmiah Akuntansi No. 4.

Putri, Ni Wayan Krisnayani \& Merkusiwati. 2014. Pengaruh Mekanisme Corporate Governance, Likuiditas,Leverage dan Ukuran Perusahaan Pada Financial Distress. E-Jurnal Akuntansi Universitas Udayana Vol. 7 No.1:93 -106. 
Ross et al. 2008. Corporate Financial Fundamental. Mc-Graw Hill International Edition.

Sulistyanto, H Sri. 2008. Manajemen Laba : Teori Dan Model Empiris. Jakarta: Grasindo.

Wibowo, Wahyudi \& Musdholifah. 2017. Pengaruh Corporate Governance, Kinerja Keuangan dan Ukuran Perusahaan TerhadapFinancial Distres pada Sektor Pertambangan di Indonesia. Jurnal Ilmu Manajemen Vol.5 No. 3.

www.ekbis.sindonews.com(https://ekbis.sindonews.com/read/1085897/39/perusa haan) 